\title{
RESPON IMUN PADA INFEKSI JAMUR
}

\author{
Ahsani, D. $\mathbf{N}^{1}$ \\ ${ }^{1}$ Departemen Histologi Fakultas Kedokteran Universitas Islam Indonesia.
}

\begin{abstract}
ABSTRAK
Jamur merupakan organisme saprofit yang dapat menyebabkan infeksi sistemik pada pasien imunokompromais. Tiap spesies jamur memiliki respon mekanisme yang berbedabeda untuk dapat menghindari sistem imun host. Upaya penghindaran dari sistem imun host berlangsung tidak hanya terbatas pada modifikasi molekul permukaan saja, tetapi juga modifikasi pada bentuk morfologis dan modulasi pada sistem imun humoral. Artikel ini bertujuan untuk memahami lebih jauh bagaimana sistem imun host terhadap infeksi jamur, serta mempelajari bagaimana respon jamur untuk menghindar dari sistem imun host.
\end{abstract}

Kata kunci : infeksi jamur, imunokompromais, sistem imun humoral.

\section{ABSTRACT}

Fungi are saprophytic organisms that can cause systemic infections in immunocompromised patients. Each species of fungi has a different mechanisms for overcoming host immune system. The strategy of fungal to avoid host immune system is not only by modification of its surface molecules, but also by modification of morphological form and the humoral immune system modulation. The purpose of this article are to promote improvements in our understanding of the immune system responses to fungal infections and the fungal stragtegies for overcoming host immune system .

Keywords : fungal infections immunocompromised, humoral immune system.

\section{PENDAHULUAN}

Jamur merupakan mikroorganisme saprofit pada manusia yang terdapat luas pada permukaan tubuh maupun pada mukosa. Penelitian terhadap patofisiologi infeksi jamur pada manusia, relatif masih sedikit dibandingkan dengan infeksi patogen lain seperti bakteri dan parasit. Hal ini dikarenakan pada individu yang imunokompeten, jamur tidak dapat menginvasi barier proteksi mekanis yang merupakan barier pertama sistem imunitas alamiah. Infeksi jamur dapat bersifat invasif dan menginduksi infeksi opportunistik pada pasien yang imunokompromais ${ }^{1}$.

Infeksi jamur pada manusia lebih sulit ditangani dibandingkan dengan infeksi bakteri. Manusia dan jamur merupakan organisme eukariotik yang memiliki kesamaan dalam mekanisme pembentukan 
protein. Berbeda dengan jamur, bakteri merupakan organisme prokariotik yang memiliki mekanisme berbeda dalam sintesis protein dibandingkan dengan manusia. Hal inilah yang merupakan pencetus utama kesulitan dalam terapi infeksi jamur pada manusia. Oleh karena itu pengobatan pada infeksi jamur harus bersifat spesifik untuk mencegah terjadinya kerusakan pada sel manusia sebagai host,. ${ }^{2}$

Penelitian terhadap mekanisme infeksi serta respon imun tubuh terhadap infeksi jamur Aspergillus merupakan yang paling banyak diteliti. Oleh karena itu untuk dapat memahami sistem imun tubuh terhadap infeksi jamur, penulis akan membahas respon imun host terhadap Aspergillus, serta membahas bentuk mekanisme penghindaran jamur terhadap sistem imun host.

RESPON IMUN TERHADAP JAMUR Aspergillus : ALAMIAH DAN ADAPTIF

Seperti pada umumnya infeksi oleh mikroorganisme lain seperti bakteri dan parasit, respon imun tubuh terhadap jamur terdiri atas respon alamiah dan juga adaptif. Respon imun alamiah berperan sebagai barier pertahanan pertama yang melawan masuknya patogen ke dalam tubuh. Respon imun adaptif merupakan mekanisme lanjutan dari respon imun alamiah untuk dapat mengeradikasi patogen di dalam tubuh. Produk akhirnya pada respon imun adaptif adalah terbentuknya sel memori terhadap antigen spesifik. ${ }^{3}$

Infeksi Aspergilus pada host diawali dengan inhalasi konidia Aspergillus dan internalisasi ke dalam sel host. Sebagian besar konidia yang masuk dalam saluran nafas bagian atas dapat dieliminasi oleh gerakan silia epitel pseudokolumner kompleks. Respon untuk menghindari sistem eliminasi oleh host terjadi melalui produksi protein tertentu. A. fumigatus mampu mensintesis protein gliotoksin, fumagillin, serta asam helvoik yang mampu menghambat pergerakan silia, serta memfasilitasi proses internalisasi konidia

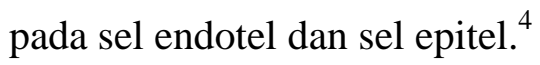

Tahap yang paling pertama dari aktivasi sistem imun terhadap konidia adalah tahap pengenalan molekul permukaan yang khas antara sel imun (makrofag) dengan konidia. Konidia yang masuk ke dalam jaringan tubuh host dapat dikenali melalui struktur Pathogen Associated Molecular Patterns (PAMPS) khas yang tidak dimiliki oleh organisme lain. Makrofag akan mengenali struktur PAPMS konidia melalui Pattern Recognition Receptor (PRRs) yang spesifik. Terdapat 2 bentuk PPRs yaitu bentuk yang 
melekat pada permukaan sel serta bentuk yang disekresikan. PPRs yang melekat pada permukaan sel imun antara lain Toll like receptors (TLRs), Mannan binding lectin (MBL) dan C-type lectin receptor/ CLR (dectin-1). PPRs yang terdapat dalam bentuk sekresi antara lain Lung surfactant proteins A dan D (SP-A and SP-D). 2,5,6,7

PPRs yang spesifik akan mengenali stuktur yang terdapat pada permukaan dinding sel jamur. TLR merupakan kelas mayor PRRs yang berperan penting dalam respon imun terhadap jamur. Dua subtipe TLR yan berperan penting dalam proses ini antar berperan penting untuk mengenali struktur glukoronoksilomanan dan O-linked mannan. Dectin-1 akan mengenali struktur $\beta$-glucan sedangkan ketiga bentuk PRRs yang tersekresi (SP-A, SP-D dan MBL) akan mengenali gugus karbohidrat pada permukaan jamur.

Pengenalan antara PRRs dengan struktur PAMPS akan menginduksi berbagai proses imun dalam rangka mengeliminasi patogen. Pengenalan PAMPS melalui dektin-1, TLR2, dan TLR4 akan meningkatkan pembentukan sitokin proinflamatori tumor necrotic factor- $\alpha / \quad$ TNF- $\alpha \quad$ (Gambar 1). ${ }^{5,6,7}$

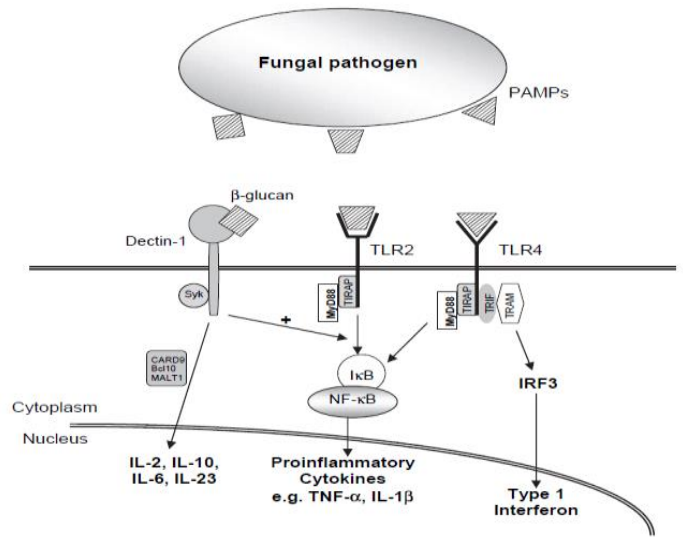

Gambar 1. Pengenalan stuktur PAMPS melalui reseptor TLR2, 4 serta dektin-1. Pengenalan stuktur PAMPS melalui reseptor TLR 2, 4 serta dectin-menginduksi pembentukan sitokin proinflamasi TNF- $\alpha$.

lain TLR2 dan TLR4. TLR2 berperan Pengenalan PAMPS melalui SP-A dan SPpenting untuk mengenali struktur zimosan, D berperan penting untuk meningkatkan fosfolipomanan serta glukuronoksilomanan kemotaksis, fagositosis, oxidative killing, (GXM) pada dinding sel jamur. TLR4 serta aglutinasi konidia. Selain itu, 
pengenalan antara PRRs dengan struktur PAMPS juga berperan tenting dalam peningkatan sekresi kemokin Macrophage Inflammatory Protein (MIP) dan protein antimikrobial. MIP-1 dan MIP-2 berperan penting dalam induksi kemotaksis ke jaringan lesi. Selain itu, kemokin ini juga berperan penting untuk menginduksi diferensiasi netrofil dan monosit menjadi makrofag. $^{2}$

Eradikasi konidia oleh sel makrofag terjadi melalui proses fagositosis. Pada tahap awal, konidia yang telah diinternalisasi oleh makrofag akan berada di dalam fagosom. Pada tahap lanjut, eradikasi konidia terjadi melalui proses asidifikasi dan pembentukan Reactive Oxygen Intermediet (ROI) di fagolisosom. Fagolisosom sendiri terbentuk dari fusi antara fagosom dengan lisosom. Sebanyak 90\% konidia yang diinternalisasi oleh makrofag akan mati dalam 24 jam. Sepuluh persen sisanya akan berkembang menjadi bentuk hifa atau tetap bertahan dalam bentuk resting conidia. ${ }^{8}$

Bentuk morfologi resting conidia, germinating conidia serta hifa merupakan aktivator potensial kaskade komplemen. Bentuk morfologi yang berbeda akan mengaktivasi komplemen dari jalur yang berbeda pula. Bentuk resting conidia akan menginduksi aktivasi komplemen melalui jalur alternatif (alternative pathways), sedangkan bentuk hifa akan menginduksi aktivasi komplemen melalui jalur klasik (classical pathways). ${ }^{2}$

Hifa yang tumbuh ke ruang ekstraseluler (menembus makrofag) akan menginduksi aktivasi sistem imun ekstraseluler. Aktivasi sistem imun ekstraseluler ditandai dengan terjadinya proses inflamasi, sekresi ROI ke ekstraseluler, peningkatan kemotaksis netrofil dan peningkatan produksi peptide antimikrobial. Terjadinya proses inflamasi ditandai dengan peningkatan sitokin TNF- $\alpha$ , interleukin-15 (IL-15) dan IL-8. ${ }^{2}$ Sebanyak 50\% hifa yang tumbuh ke ruang ekstraseluler akan mati dalam 2 jam. ${ }^{1}$

Resting conidia berupakan bentuk yang resisten terhadap proses eradikasi oleh sel imun. Bentuk morfologi ini lebih resisten terhadap sekresi ROI dan kationik peptide oleh sel netrofil. Selain itu, internalisasi resting konidia oleh netrofil hanya mampu menginduksi proses degranulasi dan respiratory burst yang lemah. Respon netrofil akan meningkat jika bentuk morfologi resting konidia ini berubah menjadi bentuk morfologi resting conidia swelling. ${ }^{1}$ Pada pasien neutropeni, peranan netrofil akan digantikan oleh sel 
Natural killer (NK) dan platelet. Namun bagaimana mekanisme imun pada NK maupun platelet ini masih belum jelas. ${ }^{1}$

Sel dendritik (DCs) merupakan sel yang menghubungkan antara sistem imun alamiah dan adaptif. DCs mampu memfagositosis jamur dalam bentuk bentuk
Respon imun seluler (Cell

Mediated Immunity/ CMI) akan terinduksi oleh pengenalan konidia Aspergillus oleh DCs melalui TLR4. Sel imun yang berperan dalam pada mekanisme imun ini adalah Sel Th1. Aktivasi sel Th1 akan menginduksi terjadinya proses inflamasi untuk

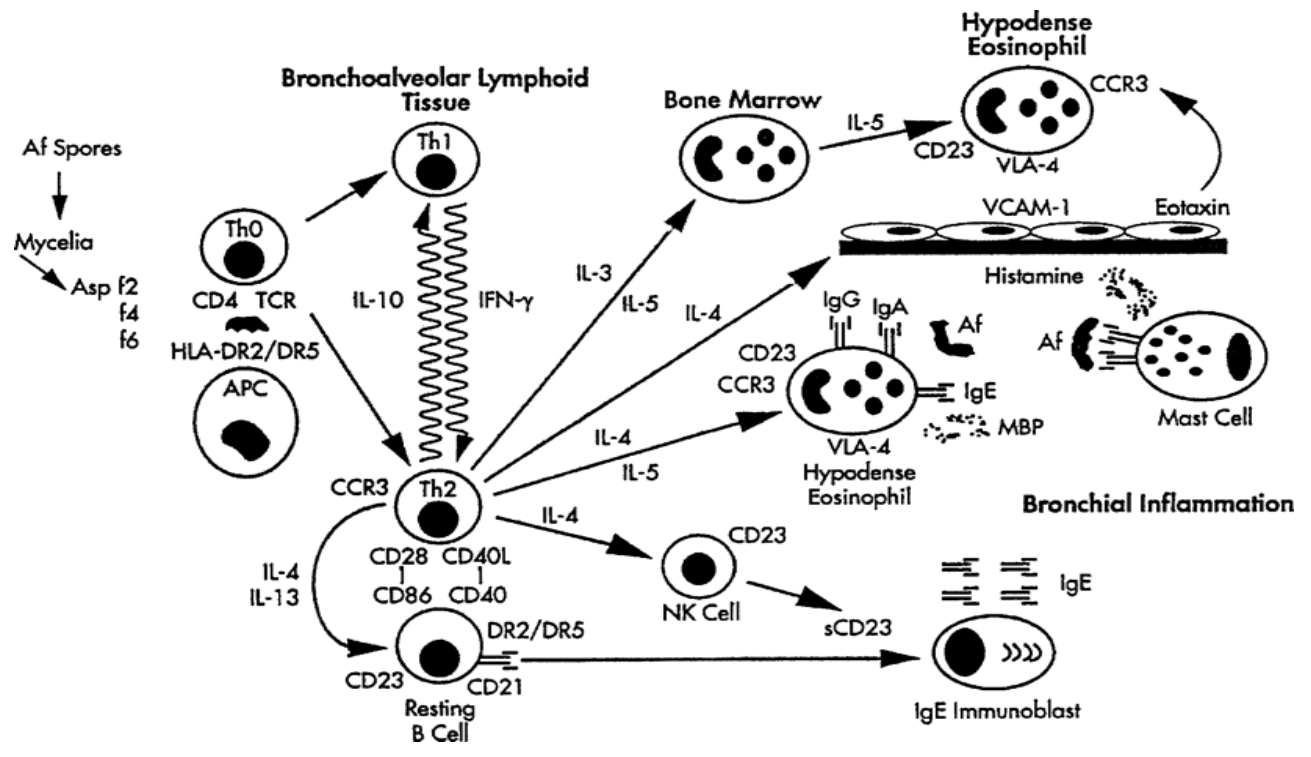

Gambar 2. Respon imun humoral pada infeksi jamur. Respon imun humoral terjadi melalui pembentukan Th2, differensiasi sel B, produksi IgE serta aktivasi sel efektor eosinofil dan sel mast untuk proses degranulasi.

konidia maupun hifa melalui PRRs yang berbeda. DCs pulmoner yang telah menginternalisasi Aspergillus akan menjadi matur dan bermigrasi ke organ limfoid sekunder untuk menginduksi sistem imun adaptif (pembentukan sel $\mathrm{T}$ helper). Pengenalan morfologi tertentu oleh TLR2 dan TLR4 pada permukaan DCs akan menstimulus respon imun yang berbeda. ${ }^{3}$ menghilangkan patogen intraseluler. Beberapa sitokin proinflamasi yang perperan dalam mekanisme ini antara lain interferon-y (IFN- $-\gamma)$, IL-6, IL-12, TNF- $\alpha$ serta Granulocyte-Macrophage Colony Stimulating Factor (GM-CSF). ${ }^{7}$

Respon imun humoral akan terinduksi oleh pengenalan hifa Aspergillus oleh DCs melalui TLR 2. Sel imun yang berperan dalam mekanisme imun ini adalah 
Sel Th2. Aktivasi sel Th2 akan akan memfasilitasi terjadinya infeksi yang menginduksi aktivasi sel plasma (sel kronis dan progresif, dimana proses efektor) untuk mensekresikan immunoglobulin pada permukaan selnya untuk menjadi antibodi. Proses isotope switching akan memfasilitasi terbentuknya berbagai antibodi oleh sel plasma. Antibodi utama yang berperan pada infeksi jamur adalah IgE. IgE akan menginduksi reaksi hipersensitivitas tipe cepat (alergi) melalui mekanisme Antibody Derived Cell Cytotoxicity (ADCC). Mekanisme ADCC dimulai dengan pengenalan antara kompleks IgE pada permukaan hifa Aspergillus dengan sel efektor (eosinofil, basofil, sel mast) melalui $\mathrm{Fc}$ reseptor. Proses ini akan menginduksi terjadinya degranulasi mediator histamin, leukotrien, dan Major Basic Protein (MBP) dari sel efektor. Proses degranulasi akan menginduksi terjadinya kerusakan jaringan. $^{2}$

Bentuk morfologi hifa memiliki karakteristik khas yang mampu menginduksi terjadinya infeksi kronis. Bentuk hifa mampu memproduksi kolagenase, elastase dan protease yang berperan penting dalam destruksi matriks ekstraseluler secara lansung. Bentuk morfologi hifa juga mampu melekat pada remodeling jaringan akan diikuti oleh terjadinya kerusakan jaringan kembali (Gambar 2). ${ }^{2}$

Respon imun Th1 berperan sebagai faktor proteksi terhadap infeksi jamur dibandingkan dengan Th2. Aktivasi pada sistem imun hormonal digunakan oleh jamur untuk menghindar dari sistem imun seluler. Hal ini dianggap menguntungkan bagi jamur oleh karena jamur dapat menghindar dari aktivitas respiratory burst dan juga menghindar dari terdapatnya sekresi antifungal yang diinduksi oleh aktivasi sel Th1. ${ }^{2}$

\section{$\begin{array}{lrr}\text { MEKANISME } & \text { JAMUR } & \text { DALAM } \\ \text { MENGHINDARI } & \text { SISTEM } & \text { IMUN } \\ \text { TUBUH } & & \end{array}$} Sistem imun yang sempurna akan mampu mengeliminasi seluruh patogen (bakteri, parasit maupun jamur) yang masuk dalam tubuh host. Namun, pada kenyataannya tiap patogen mempunyai mekanisme tertentu untuk dapat menghindar dari sistem imun host. Secara umum terdapat enam mekanisme yang memungkinkan bagi jamur untuk menghindar dari sistem imun host. Mekanisme tersebut antara lain : matriks ekstraseluler. Kedua hal inilah yang 
1. Menghindari pengenalan struktur PAMPs yang menginduksi respon inflamasi

Jamur mampu beradaptasi terhadap keadaan lingkungan yang tidak menguntungkan bagi perkembangannya melalui perubahan bentuk morfologi (switching fenotip).

a. A. fumigatus menghindari sistem imun proinflamasi (respon imun seluler) melalui pembentukan hifa. Bentuk morfologi hifa akan dikenali oleh sel imun humoral melalui struktur TLR4. ${ }^{6,7}$

b. C. Albicans menghindari sistem imun seluler melalui bentuk pada struktur $\beta$-glukan (Gambar 3 dan 4).6,7

c. Histoplasma capsulatum menghindari sistem imun seluler melalui penutupan struktur $\beta$-glukan oleh $\alpha(1,3)$ glukan. Struktur $\alpha(1,3)$ glukan ini tidak mampu dikenali oleh PRRs. ${ }^{7}$

d. Cryptococcus neoformans menghindari sistem imun seluler melalui penutupan struktur glukoronoksilomanan (GXM) dengan kapsul ekstraseluler. Hal ini akan mengakibatkan penekanan produksi sitokin proinflamasi seperti

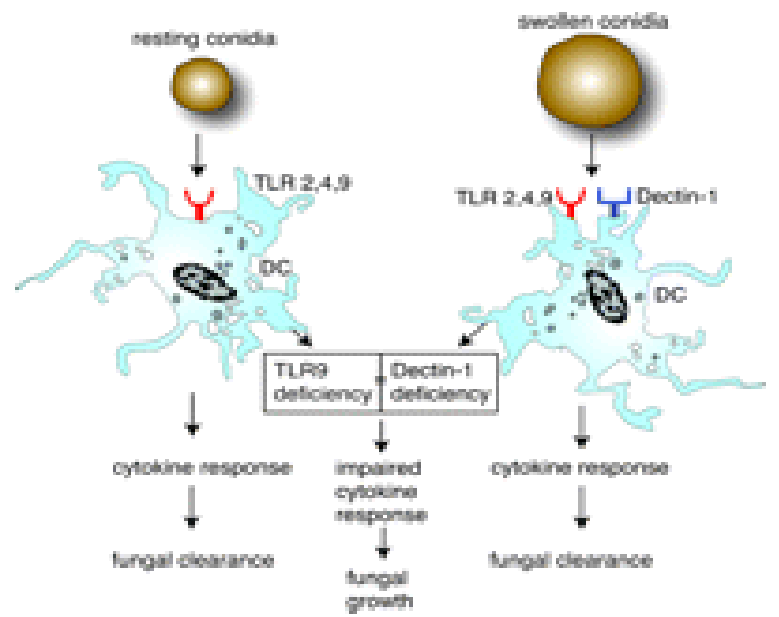

Gambar 3 Mekanisme menghindari respon imun tubuh pada A. fumigatus Perubahan bentuk morfologi menjadi bentuk hifa mengakibatkan hilangnya upaya pengenalan oleh reseptor TLR4.

nas (budding). Bentuk morfologi ini akan sulit dikenali oleh dektin-1 oleh karena terjadinya penutupan
TNF- $\alpha$ dan IL- $1 \beta{ }^{7}$

e. Coccidiodes Posadasii menghindari sistem imun seluler melalui sekresi metalloproteinase (Mep1) yang 


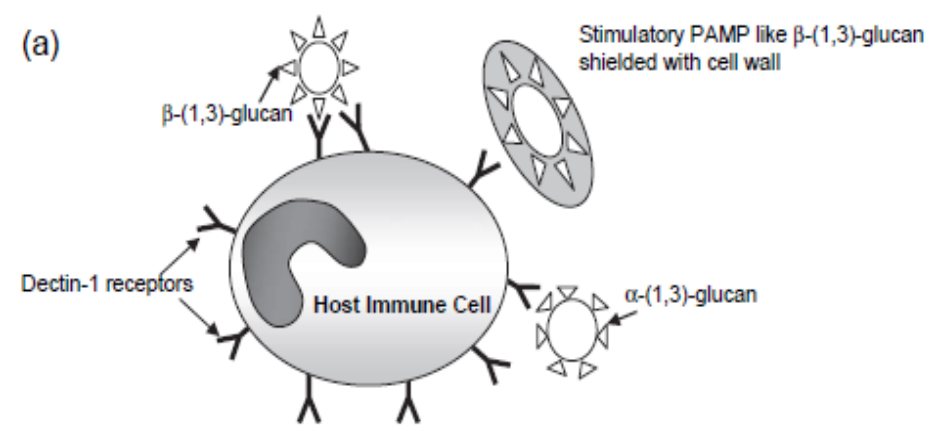

Gambar 4. Mekanisme penghindaran pengenalan struktur PAMPS. Penutupan struktur $\beta$ glukan dengan $\alpha 1,3$ glukan berperan untuk menghindari respon imun proinflamasi yang akan mengeradikasi jamur.

mampu mendestruksi struktur

PAMPs Coccidiodes Posadasii di

fase endospora yang berupa SOWgp. ${ }^{7}$

\section{Modulasi sinyal inflamasi}

a. C. Albicans dan A. fumigatus menghindari sistem imun seluler melalui induksi pengenalan PAMPs melalui TLR2. Aktivasi sistem imun humoral akan menghambat aktivitas antihifa dan proses respiratory bust oleh monosit. ${ }^{2,7}$ b. C. neoformans memiliki kapsul yang mengandung polisakarida glukoronoksilomanan yang merupakan aktivator antiinflamasi IL-10 oleh monosit dan aktivator sitokin proinflamasi Th2. ${ }^{7}$

c. C. neoformans memiliki pigmen melanin yang akan menginduksi sekresi sitokin IL-4 dari Th2. ${ }^{7}$

d. Blastomyces dermatitidis (penyebab mikosis pulmoner dan sistemik yang progresif) menghindari sistem imun

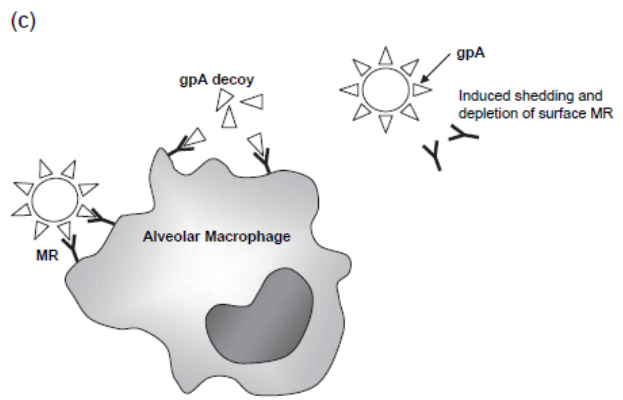

Gambar 5. Mekanisme menghindar dari sistem imun dengan cara pembentukan molekul pengumpan. Pengenalan struktur GpA jamur (PAMPS) yang immature akan mengakibatkan terjadinya blok pada reseptor manose serta akan menghambat fungsi fagositosis sel makrofag. 
dengan cara membatasi produksi matur tersusun atas komplek sitokin pro-inflamasi TNF- $\alpha$. Hal ini diperantarai oleh perlekatan antara molekul adhesi dan faktor virulensi BAD1 yang berada dipermukaan jamur dengan reseptor komplemen 3 pada permukaan makrofag. ${ }^{7}$

3. Pembentukan molekul pengumpan pada permukaan sel jamur (Shedding of decoy conents)

Pada dasarnya pembentukan molekul pengumpan yang mirip dengan struktur PAMPS pada permukaan sel jamur akan menggantikan fungsi pengenalan antara PAMPS dengan PRRs yang sesuai. Dengan terjadinya pengenalan pada struktur ini, maka akan terjadi bloking pada reseptor PRRs. Pneumocystis jiroveci (sebelumnya dikenal dengan Pneumocystis carinii) membentuk strukur kompleks antigen permukaan yang imatur sebagai molekul pengumpan. Antigen permukaan Pneumocystis jiroveci pada keadaan

glikoprotein A (GpA) yang terglikolisasi dengan mannose, glukosa, dan galaktosa. Antigen ini akan dikenali oleh reseptor mannose pada permukaan makrofag alveolar (AMs). Pembentukan kompleks antigen yang imatur akan mengakibatkan terjadinya blok secara kompetitif terhadap fungsi reseptor mannose. Peristiwa ini akan mengakibatkan terjadinya gangguan fungsi fagositosis pada sel makrofag. Selain itu, Pneumocystis juga mampu menghindari pengenalan reseptor manose yang terdapat dalam bentuk sekresi (Gambar 5). ${ }^{2}$

\section{Menghindar dari respon fagositosis}

Salah satu cara yang dilakukan oleh jamur untuk dapat menghindari immune surveillance dan fagositosis, adalah dengan cara bersembunyi pada sel yang bersifat nonfagositik (Gambar $6)$.

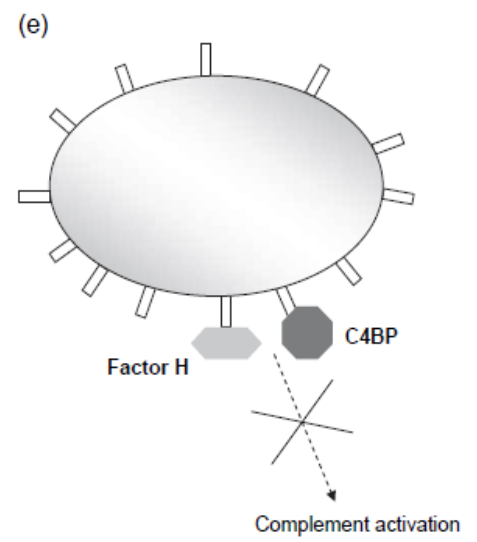

Gambar 8. Mekanisme penekanan aktivasi komplemen oleh A. fumigates. Konidia A. fumigates menekan (down regulate) kaskade komplemen melalui pengikatan faktor $\mathrm{H}$ (protein regulator jalur alternatif) serta faktor FHL-1 dan C4BP (protein regulator jalur klasik). 
a. Konidia A. fumigatus dapat diinternalisasi di dalam sel lini epithelial manusia dan mampu hidup dalam jangka waktu yang lama. Konidia yang diinternalisasi oleh sel epitel saluran nafas akan menghambat produksi sitokin pro-inflamasi IL-6 dan IL-8, sedangkan konidia yang diinternalisasi oleh sel pneumosit tipe II akan bersembunyi didalam late endosom. ${ }^{7}$

b. C. albicans mampu menginduksi internalisasi oleh sel endothelial host melalui $N$-cadherin. ${ }^{2}$

c. C. neoformans mampu menginduksi internalisasi pada sel endothelial mikrovaskuler sehingga mampu melewati sawar darah otak dan menyebabkan meningitis. ${ }^{7}$

5. Kemampuan bertahan dengan cara membentuk morfologi yang baru (persistence despite adversity).

Pada dasarnya melalui mekanisme ini, jamur yang telah diinternalisasi akan bertahan dari mekanisme destruksi sel fagositik dengan cara membentuk morfologi yang baru. $^{7}$

a. C. neoformans membentuk varian koloni mukoid yang mampu memproduksi kapsul polisakarida GXM yang lebih besar. Hal ini akan mengakibatkan kesulitan bagi makrofag alveolar untuk dapat melakukan fagositosis. C. neoformans yang berhasil difagositosis oleh makrofag juga akan bertahaan hidup dengan cara menghambat trafficking lisosom untuk mencegah fusi dengan fagosom serta menginduksi terjadinya vakuolisasi sitoplasmik pada sel makrofag. ${ }^{7}$

b. C. albicans yang diinternalisasi dalam makrofag mampu menghindar dari proses destruksi melalui berbagai proses. Upaya yang pertama untuk menghindari proses destruksi intraseluler adalah dengan membentuk fase hibernasi. Pada tahap selanjutnya mekanisme menghindar yang dilakukan adalah melalui induksi fusi lisosom dengan fagosom pada fase dini (early endosom). Aktivasi terhadap gen $\mathrm{NO}$ scavenging flavohemoglobin, mampu mengubah zat NO yang diproduksi oleh makrofag menjadi senyawa lain dengan toksisitas yang lebih rendah. Semua proses tersebut akan memfasilitasi jamur untuk menghindari proses destruksi intraseluler sehingga mampu 
berkembang menjadi bentuk fagositik. Upaya penghindaran yang morfologi hifa. ${ }^{7}$

c. Histoplasma capsulatum dapat hidup dalam jangka panjang didalam sel makrofag dengan cara menghambat fusi fagolisosom, mengatur $\mathrm{PH}$ fagolisosom, serta menghambat pelepasan toxic superoxide radicals. ${ }^{7}$

\section{Evasi komplemen.}

Jamur memiliki dinding sel yang tebal dan bersifat resisten terhadap pembentukan Membrane Attack Complex (MAC) oleh sistem komplemen. Sekresi pigmen melanin pada permukaan konidia A. fumigates akan menghambat deposisi komplemen C3 dan menghambat aktivasi netrofil. Konidia A. fumigates juga menekan (down regulate) kaskade komplemen melalui pengikatan faktor $\mathrm{H}$ (protein regulator alternative pathways) serta faktor FHL-1 dan C4BP (protein regulator classical pathways). ${ }^{7}$

\section{KESIMPULAN}

Jamur memiliki kemampuan untuk dapat menghindari sistem imun tubuh host. Mekanisme utama yang melatar belakangi kemampuan ini adalah upaya penghindaran pengenalan struktur PAMPs spesifik yang ada pada permukaan sel jamur dari sel

\section{DAFTAR PUSTAKA}

1. Blanco, JL., Garcia, ME. 2008. Immune response to fungal infections. Veterinary Immunology and Immunopathology. 125: 47-70.

2. Shoham, S., and Levitz, S.M., 2005. The immune response to fungal infections. British Journal of Haematology. 129: 569582.

3. Romani, L., 2004. Immunity to fungal infections. Nat. Rev. Immunol. 4: 1-23.

4. Paris, S., Boisvieux-Ulrich, E., Crestani, B., Houcine, O., Taramelli, D., Lombardi, L., Latge, J.P., 1997. Internalization of Aspergillus fumigatus conidia by epithelial and endothelial cells. Infect. Immun. 65: 1510-1514.

5. Netea, M.G., Van der Graaf, C.A.A., Vonk, A.G., Verschveren, I., Van der Meer, J.W., Kullberg, B.J., 2002. The role of toll-like receptor (TLR) 2 and TLR 4 in the host defence against disseminated candidiasis. J. Infect. Dis. 185: 1483-1489. 
6. Gantner, B.N., Simmons, R.M., Underhill, D.M., 2005. Dectin-1 mediates macrophage recognition of Candida albicans yeast but not filaments. EMBO J. 24: 1277-1286.

7. Chai, L.Y.A., Netea , M.G.,. G. Vonk, A., Kullberg, B. 2009. Fungal strategies for overcoming host innate immune response. Medical Mycology. 47: 227-236

8. Latge, J.P., 1999. Aspergillus fumigatus and Aspergillosis. Clin. Microbiol. Rev. 12: 310-350.

9. Wright, J.R., 1997. Immunomodulatory functions of surfactant. Physiol. Rev. 77: 931-962. 